\title{
ANTIFUNGAL ACTIVITY OF CRUDE EXTRACTS OF SOME MEDICINAL PLANTS AGAINST FUSARIUM SOLANI (MART.) SACC.
}

\author{
Asha Kaji Shrestha and R.D. Tiwari \\ Central Department of Botany \\ Tribhuvan University, Kirtipur, Kathmandu \\ email: tiwariramdeo@yahoo.com
}

\begin{abstract}
The crude extracts of six plants viz, Allium sativum, Capsicum annuum, Artimesia vulgaris, Eupatorium adenophorum, Gaultheria fragrantissima and Phyllanthus emblica were assessed in vitro for activity against fungi Fusarium solani (Mart.) Sacc., the causal agent of dry potato tuber rot. Pathogenecity test was confirmed by inoculating the pathogen into the healthy potato tuber. The assessment of fungitoxicity was carried out by poisoned food technique using ten different concentrations $(10,20,30,40,50,60,70,80,90$ and 100\%) against the test fungus. Assessment was carried out in terms of percentage of mycelial growth inhibition of the test fungus. The extracts of all the plant species were found to be effective in inhibiting the mycelial growth. The extract of $A$. sativum completely inhibited the mycelial growth of the test fungus at the concentration of $40 \%$ and the extracts of Capsicum annum and Phyllanthus emblica inhibited the mycelial growth completely at the concentration of $100 \%$.
\end{abstract}

Key words: Plant extracts, antifungal activity.

\section{INTRODUCTION}

Antimicrobial chemicals such as benzimidazoles, aromatic hydrocarbons and sterol biosynthesis inhibitors are often used in the control of plant diseases in agriculture. However, there is a series of problems against the effective use of these chemicals in areas where the fungi have developed resistance (Brent and Hollomon 1998). In order to overcome this problem, higher concentrations of the chemicals had been used, but this increased the risk of high-level toxic residues in the products which were not beneficial for human beings and environment. Thus, there has been a growing interest on the research of possible use of plant extracts for control of pest and diseases in agriculture which are less harmful to the human health and environment (Costa et al. 2000, Duru et al. 2003).

Plant diversity serves the humankind as renewable natural resources for a variety of biologically active chemicals. These chemicals bear a variety of properties viz, antibacterial, antifungal, antiviral, anthelmintic, anticancer, sedative, laxative, cardiotonic, diuretic and others (Parajuli et al. 1998). Active constituents of the medicinal and aromatic plants have been found to 
be less phytotoxic, more systemic and easily biodegradable (Fawcett and Spencer 1970).

Fusarium solani (Mart.), the causal agent of storage rot of potato tuber, generally occurs as dry powdery white colony superficially on the infected parts. The fungus gains entry through eye spots or, wounds or, through lesions caused by other fungi or bacteria. The disease develops more rapidly under the conditions of high humidity and at temperature around $20^{\circ} \mathrm{C}$.

In culture, the colonies are whitish brown with numerous micro conidia and macro conidia. Conidiophores are short and hyaline which bear conidia. Micro conidia are oval with somewhat thicker walls, hyaline measuring 8-16×2-4 $\mu$ and may be aseptate or single septate. Macro conidia develop after 4-7 days which bear tapering ends with widest centre, little curved and measure 3555×4.5-6 $\mu$. Chlamydospores may develop after 714 days (Boyd 1952).

The present investigation aims to find out the antifungal activity of the crude extract of six medicinal plants against the test fungus.

\section{MATERIALS AND METHODS}

Source of crude plant extracts: The leaves of Artimesia vulgaris, Eupatorium adenophorum and Gaultheria fragrantissima, bulb(clove) of Allium sativum and fruits of Capsicum annuum, Phyllanthus emblica were used for the extraction. Three gram of each plant material was sterilized in $0.1 \%$ mercuric chloride followed by proper washing in distilled water and was grinded in presterilized mortar and pestle by adding $5 \mathrm{ml}$ of distilled water. The extracts were filtered and centrifuged at $500 \mathrm{rpm}$ for $3 \mathrm{~min}$ to obtain clear solution. The volume was maintained to $7 \mathrm{ml}$ and different concentrations $(10,20,30,40,50,60,70$,
80,90 and $100 \%$ ) were made for further use in the experiment.

Test fungus: Fusarium solani was isolated from the infected potato tuber using standard pathological techniques. The media used was Potato Dextrose Agar (PDA). The pure culture of the test fungus was maintained. The assessment of fungitoxicity was done by poisoned food technique (Grover and Moore 1962).

Inoculum disc: Seven days old culture of the test fungus was used for the preparation of inoculum disc of $4 \mathrm{~mm}$ in diameter.

Antifungal assay: A volume of $0.5 \mathrm{ml}$ of each concentration was aseptically poured into the petriplate followed by the addition of $9.5 \mathrm{ml}$ of melted PDA and was swirled gently to achieve thorough mixing of the contents. In the control set, no extract was used. After the solidification of the media, one inoculum disc of the test fungus was aseptically inoculated upside down at the centre of the petriplate and incubated at $25 \pm 2^{0} \mathrm{C}$.

The average diameter of the fungal colonies were measured on the $7^{\text {th }}$ day of incubation and percentage of mycelial growth inhibition was calculated (Rao and Srivastava 1994).

Mycelial growth inhibition $(\%)=\frac{g_{c}-g_{t}}{g_{c}} \times 100$

Where,

$\mathrm{g}_{\mathrm{c}}=$ growth of mycelial colony in control set after incubation period subtracting the diameter of inoculum disc.

$\mathrm{g}_{\mathrm{t}}=$ growth of mycelial colony in treatment set after incubation period subtracting the diameter of inoculum disc. 
Table 1. Mycelial growth inhibition (in percentages) by the extracts of the test plants at different concentrations.

\begin{tabular}{cccccccc}
\hline SN & $\begin{array}{c}\text { Concentr- } \\
\text { ations (\%) }\end{array}$ & $\begin{array}{c}\text { Allium } \\
\text { sativum }\end{array}$ & $\begin{array}{c}\text { Capsicum } \\
\text { annuum }\end{array}$ & $\begin{array}{c}\text { Artimesia } \\
\text { vulgaris }\end{array}$ & $\begin{array}{c}\text { Eupatorium } \\
\text { adenophorum }\end{array}$ & $\begin{array}{c}\text { Gaultheria } \\
\text { fragrantissima }\end{array}$ & $\begin{array}{c}\text { Phyllanthus } \\
\text { emblica }\end{array}$ \\
\hline 1. & 10.0 & 47.7 & 54.5 & 61.38 & 68.18 & 45.4 & 61.36 \\
2. & 20.0 & 56.8 & 63.36 & 63.36 & 70.45 & 50.0 & 63.36 \\
3. & 30.0 & 72.72 & 68.1 & 63.36 & 70.45 & 52.2 & 65.9 \\
4. & 40.0 & 100.0 & 70.45 & 65.9 & 75.0 & 52.2 & 70.45 \\
5. & 50.0 & 100.0 & 93.1 & 65.9 & 75.0 & 54.5 & 75.0 \\
6. & 60.0 & 100.0 & 95.4 & 65.9 & 75.0 & 56.8 & 81.18 \\
7. & 70.0 & 100.0 & 95.4 & 70.4 & 77.2 & 63.3 & 86.36 \\
8. & 80.0 & 100.0 & 97.7 & 75.0 & 79.5 & 65.9 & 93.18 \\
9. & 90.0 & 100.0 & 97.7 & 81.18 & 81.18 & 75.0 & 95.0 \\
10. & 100.0 & 100.0 & 100.0 & 84.0 & 84.0 & 81.1 & 100.0 \\
\hline
\end{tabular}

\section{RESULTS AND DISCUSSION}

All the extracts showed inhibition effects on the growth of the test fungus (Table 1). Among the tested plant species, Allium sativum markedly inhibited the fungus growth even at a low concentration of $40 \%$ followed by Capsicum annuum, Phyllanthus emblica, Eupatorium adenophorum, Artimesia vulgaris and Gaultheria fragrantissima.

The inhibition of the mycelial growth of the test fungus was found to be 47.7 to 100 percent by the extract of A.sativum; 54.5 to 100 percent by the extracts of Capsicum annuum; 61.36 to 100 percent by the extracts of Phyllanthus emblica; 68.18 to 84 percent by the extracts of Eupatorium adenophorum; 61.3 to 84 percent by the extracts of Artimesia vulgaris; 45.4 to 81.18 percent by the extracts of Gaultheria fragrantissima at the concentration of 10 to $100 \%$. The extracts of Allium sativum was found to be most effective for the control of the test fungus. The plant species showed reasonable effects among themselves. Relative variation in the content of active chemicals in the extracts was speculated to be one of the evident reasons.

\section{ACKNOWLEDGEMENT}

The authors are highly indebted to the Central Department of Botany, Tribhuvan University for providing the laboratory facilities during the entire work.

\section{REFERENCES}

Boyd, A.E.W. 1952. Dry-rot disease of the potato. Ann. Appl. Biol. 39:322-357.

Brent, K.J. and D.W. Hollomon. 1998. Fungicide resistance: the assessment of risk. FRAC, Global Crop Protection Federation, Brussels. Monograph No. 2, pp. 1-48.

Costa, T.R., F.L.F. Fernandes, S.C. Santos, C.M.A. Oliveria, L.M. Liao, P.H. Ferri, J.R. Paulo, H.D. Ferreira, B.H.N. Sales and M.R.R. Silva. 2000. Antifungal activity of volatile constituents of Eugenia dysenterica leaf oil. J. Ethnopharm. 72(1-2):111-117.

Duru, M.E., A. Cakir, S. Kordali, H. Zengin, M. Harmandar, S. Izumi and T. Hirata. 2003. Antifungal activities of the leaves of three 
Pistacia species grown in Turkey. Fitoterapia. 74(1-2):170-176.

Fawcett, C.H. and D.M. Spencer. 1970. Plant chemotherapy with natural products. Ann. Rev. Phytopath. 8:403-418.

Grover, R.K. and J.D. Moore. 1962. Toximetric studies of fungicides against brown rot organism. Sclerotina fruticola. Phytopathology. 52:876-880.

Parajuli, D.P., A.R. Gyawali and B.M. Shrestha. 1998. A Manual of the Important Non-Timber
Forest Products in Nepal. Training and manpower development in C.F.M. Pokhara, Nepal.

Rao, G.P. and A.K. Srivastava. 1994. Toxicity of essential oils of higher plants against fungal pathogens of sugarcane. Current Trend in Sugarcane Pathology. (eds.) Rao, G.P., A.G. Gillasple, P.P. Upadhaya, A. Bergamin, V.P. Agnihotri and C.T. Chen. International Books and Perodicals Supply Service, Pitampura, Delhi, pp. 347-365. 